STUDIA ROSSICA POSNANIENSIA, vol. XXXIX: 2014, pp. 61-70. ISBN 978-83-232-2747-2. ISSN 0081-6884. Adam Mickiewicz University Press, Poznań

\title{
ПАРОДИЯ В АНЕКДОТЕ
}

\author{
PARODY IN JOKES
}

\section{ОЛЬГА ФРОЛОВА}

ABSTRACT. The article deals with using different types of parody in jokes. The features of speech used in texts of different kinds and genres (an SMS, ad, email, prayer and opinion poll) are parodied in jokes. The purpose of parody is to imitate or discredit the original genre.

Ольга Фролова, Московский государственный университет имени М.В. Ломоносова, Москва - Россия.

\section{Традиционно пародию рассматривают как}

жанр литературно-художественной имитации, подражание стилю отдельного произведения, автора, литературного направления, жанра с целью его осмеяния. Автор пародии, сохраняя форму оригинала, вкладывает в нее новое, контрастирующее с ней содержание, что по-новому освещает пародируемое произведение и дискредитирует его: „пародичность достигается несоответствием стиля и тематического материала речи $[. . .]^{\prime \prime} 1$

и связывают с авторской литературой². Данный жанр предусматривает двойной диалог: с одной стороны, отправителя и адресата текста, с другой стороны, пародируемого и пародирующего текста. При этом для восприятия пародии важны не только пародийная функция текста, но и информационная „согласованность” адресанта и адресата, способность последнего найти и понять текстовый диалог. Как писал Б.М. Томашевский, „пародия всегда представляет как фон, от которого она отталкивается, другое литературное произведение (или целую группу литературных произведений)"3.

Для того чтобы выявить характер диалога текстов, обратимся к основополагающей статье о пародии. Ю.Н. Тынянов особо остановился на взаимодействии двух текстов при пародировании: „под на-

${ }^{1}$ Б. Т о м а ш е в с к и й, Теория литературы. Поэтика, 5-е изд. Москва-Ленинград 1931, с. 26.

2 Г.Е. Б е н, Пародия, [в:] Краткая литературная энииклопедия. В 9-ти тm. Москва 1962-1978; т. 5, Москва 1968, стлб. 604.

${ }^{3}$ Б. Т о м а ш е в с к и й, Теория ^итературы. Поэтика, Ленинград 1925, с. 161. 
правленностью мы будем понимать не только соотнесенность какого-либо произведения с другим, но и особый упор на эту соотнесенность" 4 . Тынянов предлагал также различать пародичность и пародийность, т.е. пародическую форму и пародийную функцию5

Дело в том, что есть более и менее устойчивая связь пародической формы и пародийной функции; есть условия для того, чтобы эта функция не изменялась и не превращалась в служебную. Условия эти заключаются в том, что произведения пародирующее и пародируемое могут быть связаны не только в сходных элементах (ритме, синтаксисе, рифмах и т.д.), но и в несходных - по противоположности. Иными словами, пародия может быть направлена не только на произведение, но и против него

О снижающем переосмыслении в пародии писал и А. Морозов 7 .

В современном литературоведении пародию относят к интертекстуальным явлениям. Н. Пьеге-Гро пишет, что при пародировании два текста находятся между собой в отношении деривации ится на трансформации исходного текста. Ссылаясь на Палимпсест Ж. Женетта9', Пьеге-Гро показывает, что первоначально стилизация и пародия не различались. Пародия обособилась как жанр в начале XIX в. Наиболее яркой является бурлескная травестия, в которой при сохранении сюжета повествование переводится в низкий стиль. „Наибольший эффект пародия производит тогда, когда она точно следует тексту, который она деформирует" 10 .

Наша цель - выяснить, каковы рамки и механизмы пародии в фольклорном жанре анекдота. По нашему мнению, пародия в анекдоте зависит от внутрижанровой типологии и выражается на двух уровнях: a) речевого поведения персонажа и б) жанровой формы.

В качестве материала нам послужили собрания анекдотов, размещенные в Интернете.

Уровни пародийности в анекдоте обусловливаются внутрижанровой типологией. В анекдоте сильной позицией текста является неожиданная смешная концовка. Но внутри жанра анекдотами носители языка и культуры интуитивно называют весьма разные тексты. Говоря

4 Ю.Н. Т ы н я н о в, О пародии, [в:] его же, Поэтика. История литературы. Кино, Москва 1977, с. 289.

5 Там же, с. 290.

${ }^{6}$ Там же, с. 291. Заметим, что в данном случае терминология Томашевского и Тынянова не совпадает.

7 А. М о р о з о в, Пародия как литературный жанр, „Русская литература” 1960, № 1 , c. 50 .

${ }^{8}$ Н. П ь е г е - Г р о, Введение 8 теорию интертекстуальности, Москва 2008, с. 95.

${ }^{9}$ G. G e n e t t e, Palimpsest. La littérature au second degree, Paris 1982.

10 Там же. 
о внутрижанровой типологии, мы выделяем пять подтипов анекдотов: закон, случай, сцену, толкование и метажанровый анекдот (анекдот-пародию) ${ }^{11}$.

Анекдот-закон (пример 1) соотноси́м с пословицей, отображает квалитативные характеристики ситуации или ее участников - их постоянные признаки, а также повторяющиеся явления. В этом типе анекдотов представлены так называемые вневременные, гномические, предикаты.

(1) Злоупотреблять - вредно. А НЕ злоупотреблять - глупо, [http://www.anekdot. ru/a/an9812/a981233;10.html].

Анекдот-случай повествует о единичном происшествии. К этому типу относятся многие тексты из тематической серии анекдотов о Штирлице.

(2) Штирлии подумал. Ему понравилось. Он подумал еще раз, [http://webideas. com/shtirlits/thinking.htm].

Анекдот-сцена состоит из монологической части и диалога персонажей, разворачивающегося как бы на глазах адресата. В некоторых текстах монологический ввод опускается.

(3) - Мама, можно я пойду поиграю в новом детском городке?

- Нет, сынок, не успеешь, сейчас его осмотрит наш Президент и его перевезут в другой двор, [http://anekdotov.net/anekdot/].

Анекдот-толкование, как правило, имеет вопросно-ответную форму, когда в ответе проясняется либо характер одного из участников ситуации, либо обстоятельства происходящего. В русскоязычной традиции толкование представлено тематической серией анекдотов об армянском радио.

(4) - Когда родилась демократия?

- Когда Бог подвел Адама к Еве и сказал: „Выбирай себе жену”, [http://joyreactor. cc/post/256965].

Метажанровый анекдот, или анекдот-пародия, воспроизводит неожиданную концовку как сильную жанровую позицию, но при этом воспроизводит форму другого жанра.

Как правило, пародирование речевого поведения и жанра редко совмещаются в пределах одного текста. В первом случае адресат соотносит речь прототипа и персонажа. Яркая реплика прототипа, переосмысляясь, переходит в прямую речь персонажа.

Продемонстрируем пародию на речевое поведение на примере. Так Б.Н. Ельцин со словами „не так сели” „на заседании правительствен-

11 О.Е. Ф р о л о в а, Мир, стоящий за текстом: референциальные механизмы пословицы, анекдота, волшебной сказки и авторского повествовательного художественного текста, Москва 2007, с. 90-102. 
ного оргкомитета, состоявшемся 5 мая 1999 года, пересадил будущего премьера С.В. Степашина поближе к себе", [http://www.youtube.com /watch?v=WF1NSc94uQQ]. Это происшествие породило анекдот:

(5) Осень 2000 года. Ельичин поднимает голову, долго и пристально осматривает окружающих. Наконеи, произносит, с трудом выговаривая слова: „Не так сели, понимаешь... Христенко, пересядьте на нары к Аксененко... И не деритесь!”, [http:// polithum. $\mathrm{ru} / \mathrm{tag} /$ boris-nikolaevich-elcin/].

Отличие пародии на речевое поведение от других форм пародии в том, что пародируется не текст, а высказывание, человек в его индивидуальных речевых проявлениях. Ясно, что место такой пародии - в анекдоте-сцене, т.к. именно эта жанровая разновидность приспособлена для иконического воспроизведения речи.

Пародия, воспроизводящая „чужую” жанровую форму, может быть разнообразной, ориентирующейся на разных текстовых доноров: рекламу, объявление, СМС, молитву, социологический опрос. Мы полагаем, что список пародируемых в анекдоте жанров принципиально открыт. Узнаваемость исходного пародируемого текста в анекдоте и позволила нам объединить такие анекдоты в самостоятельный жанровый подтип.

В анекдоте-объявлении можно выделить частный (примеры 6, 7) и коллективный субъект речи (пример 8).

(6) Юноша с дефектом зрения ищет девушку, приятную на ощуль, [http://www.anecks. $\mathrm{ru} / 13 \_1 . h \mathrm{html}$.

(7) Одинокий мужчина ищет одинокую женщину, с целью создания одинокого ребёнка, [http://anekdoti.ru/jokes.php?joke_category=84].

(8) Уважаемые жильцы, в связи с неожиданно возникшими техническими обстоятельствами, завтра в вачем доме будут отключены горячая, холодная вода, газ, электричество, вас выведут на улииу, где и расстреляют.

С уважением, администрация, [http://waldo.narod.ru/64A.htm, № 632].

Анекдот-реклама массово появляется в постсоветскую эпоху, когда начинается новый, рыночный, период российской экономии, развивается производство потребительских товаров и у населения страны появляется возможность выбора разных товаров и услуг. Анекдот появляется как реакция на многочисленные навязчивые повторы и избранные пиар-менеджерами и скрипт-райтерами выразительные средства, которые дискредитируются в анекдоте. Предложение неожиданных (а иногда абсурдных) услуг и, порой, бесполезных товаров и обеспечивает анекдотичность текста.

(9) ЧП случилось в лаборатории „Hиggies” при испытании нового подгузника. Оказалось, что новый подгузник не только дышит, но и думает, а после использования грязно ругается, [http://anekdoty.onru.ru/anekdoty/anegdoty/20/page5.html]. 
Строго говоря, пример 9 не повторяет дословно текст о детских подгузниках, а следует за метафорическим и метонимическим переносами в рекламе: дышать - „поглощать кислород через кожный покров"12; но в тексте рекламы дышит не кожа, а само средство детской гигиены. Анекдот возвращает глаголу и имени прямые номинативные значения: так, слово подгузник переходит из класса неодушевленных в одушевленные, и, как следствие, этому субъекту приписываются и другие предикаты, сочетающиеся с личными существительными: думает, ругается.

В анекдоте-СМС, как и в объявлении, воссоздается стиль личных сообщений (пример 10) и официальных объявлений оператора (пример 11).

(10) SMS бывщему: „Привет, дорогой! Как живёшь? Как локти? Вкусные?”, [http://pda.anekdot.ru/tags/\%F1\%EC\%F1].

(11) Уважаемый Абонент, Вы откиючены за разбазаривание государственных секретов по нашей сети, [http://sms-ok1.narod.ru/prikol.html].

Анекдоты-молитвы представляют собой переделки канонического евангельского текста:

Отче наш, Иже еси на небесех! Да сьятится имя Твое, да приидет Царствие Твое, да будет воля Твоя, яко на небеси и на земли. Хлеб наш насущный даждь нам днесь; и остави нам долги наша, якоже и мы оставляем должником нашим; и не введи нас во искушение, но избави нас от лукаваго. Ибо Твое есть Царство и сила и слава во веки. Аминь (Матф. 6: 9-13).

Анализируя молитву, можем выделить несколько позиций, на которые опирается трансформированный текст: а) обращение к Богу, б) восхваление его, в) просьба дать недостающее, г) просьба охранить от всевозможных опасностей, д) выражение уверенности во всесильности Господа, е) финальная формула, подтверждающая истинность текста „да будет так".

Нельзя сказать, что молитва является новым текстом: в работах М.Л. Лурье и С.В. Алпатова приведены студенческая и солдатская молитвы ${ }^{13}$. Как отмечает М.М. Бахтин, из античности христианская культура заимствовала традицию сатурналий, что отразилось в народных травестийных евангелиях, представляющих собой переделки канонических текстов, а также в карнавализации христианских текстов и обрядов.

12 Большой толковый словарь, под ред. С.А. Кузнецова, Санкт-Петербург 2002, c. 292.

13 М.Л. Л у р ь е, Пародийная поэзия школьников, [в:] Русский школьный фольклор, Москва 1998, с. 430-517; С.В. А л п а т о в, Солдатский „Отче наш": генезис и эволюиия народной сатиры XVIII-ХХ вв., „Традиционная культура” 2011, № 4, с. 166-172. 
В дальнейшем развитии смеховой латинской литературы создаются пародийные дублеты буквально на все моменты церковного культа и вероучения. Это так называемая „parodia sacra”, то есть „священная пародия”, одно из своеобразнейших и до сих пор недостаточно понятых явлений средневековой литературы. До нас дошли довольно многочисленные пародийные литургии (Литургия пьянии, Литургия игроков и др.), пародии на евангельские чтения, на молитвы, в том числе и на священнейшие (Отче наш, Ave Maria и др.), на литании, на церковные гимны, на псалмы, дошли травестии различных евангельских изречений и т.п. [...] Литература эта почти необозрима. И вся она была освящена традицией и в какой-то мере терпелась церковью. Часть ее создавалась и бытовала под эгидой „пасхального смеха” или „рождественского смеха", часть же (пародийные литургии и молитвы) была непосредственно связана с „праздником дураков" и, возможно, исполнялась во время этого праздника ${ }^{14}$.

Можно сказать, что в современной российской словесности эту традицию продолжает Евангелие от Митьков.

Трансформированные молитвы могут быть ориентированы на объект: ситуации, которые адресант хочет приблизить и которых хочет избежать, или же сам текст становится характеристикой адресанта.

Объектно ориентированной молитвой можно считать следующий текст:

(12) Господи, если в чем виноваты мы перед тобой, то наказал ты нас уже Перестройкой и Приватизаиией; смилуйся же над нами и не допусти еще и Модернизации с Инновациями, [http:// www.xa-xa.org/2008/07/28/molitva-studenta. html].

Профессионально ориентированными молитвами мы считаем примеры 13, 14, 15, 16, 17, 18.

Можно предположить, что молитва студента, размещенная в Интернете, восходит к более старому школьному фольклору (пример 13).

(13) Избавь меня, Боже,

От декана рожи,

От контрольной близкой,

От оиенки низкой,

От зачета стремного,

От стакана неполного,

От похмелья наутро

И от пары занудной,

От работы курсовой,

От лабы чумовой,

От задания индивидуального,

От друга 8 стельку пьяного,

От скуки и тоски,

От ответа у доски,
От нехватки друзей,

Да пивка мне налей,

Дай еды до отвала,

Чтоб плохо мне стало.

Дай мне выспаться сладко

В своей теплой кроватке.

Отвелеки, Боже, препода,

Чтобы шпор не заметил он.

Укажи мне на экзамене легкий билет,

Чтоб его лишь учил(а) я, остальные нет.

Зачет мне, о Боже, схалявь.

Степуху немножко прибавь.

Сессию отодвинь.

Вот и все... аминь...

14 М.М. Б а х т и н, Творчество Франсуа Рабле и народная культура средневековья и Ренессанса, Москва 1990, с. 20. 
Аналогичный текст, записанный в 1984 г., приведен в публикации М.Л. Лурье ${ }^{15}$.

Профессиональные молитвы записаны и проанализированы разными собирателями: так, С.В. Алпатов описал солдатский Отче нащ․ В социальных сетях обнаруживается подобный текст.

(14) Отче наш-солдатский! Да спаси нас Бог! От ночных тревог! От подвема раннего! Oт крика дневального! От самоволок разных! От девах заразных! От учении тактических! От работ физических! От овса и перловки! От строевой подготовки! Oт пайки малого веса! От старшины балбеса! От утреннего развода! От командира взвода! Да превратил бы ты господи! Море Балтийское в водку Российскую! А море Азовское в пиво ЖигулеВское!!! Аминь, [http://vk.com/id65019653\#/wall65019653_707].

Аналогично профессионально ориентированными мы считаем молитвы специалиста по компьютерным технологиям. Молитва айтишника или программиста, в разных версиях, легко опознается по профессионализмам, большинство из которых представляют заимствования, причем данные в кириллической и латинской графике: клава, коннект, провайдер, Bupyc, PC, Basic, Exception Error, а также названия клавиш ENTER, в том числе Ctrl + Alt + Delete и RESET, нажатие которых позволяет перезагрузить компьютер. Показательна также замена обращения Боже на Спутник. При явном сходстве и использовании одних и тех же механизмов - опоре на профессиональную лексику, концовки молитв разнятся: пример 15 завершается перезагрузкой компьютера, а 16 - его запуском.

(15) Спутник наш, иже еси на небеси, Да ускорится соединение твоё; Да пройдёт без помех сигнал твой; Да будет нам связь, как реальная, так и виртуальная; Мыло наше насущное дай нам на сей день; И прости ты нам кофе на клаве нашей, Как и мы прощаем плохой коннект провайдерам нашим; Не дай разорваться соединению, Но избавь нас от вируса. Аминь. Ctrl+Alt+Delete, [http://carella.ru/anecdot/58516/].

(16) Отче наш, иже еси в моем РС, Да святится имя и расширение Твое, Да придет прерывание ТВое и да будет воля ТВоя ВАSIC наш насущный дай нам, И прости нам дизассемблеры и антивирусы наши,как Копирайты прощаем мы. И не введи нас в Excерtion Error, но избавь нас от зависания, ибо Твое есть адресное пространство, порты и регистры Во имя CTRLa, ALTa и святого DELa, всемогущего RESETa во Веки веков. ENTER!!! [http://otvet.mail.ru/question/24289631/].

Примеры 16 и 17 также обнаруживают сходство, однако для менеджера компьютер не является смыслом жизни, как для программиста, а всего лишь инструментом, поэтому и количество специальных компьютерных терминов сокращается, но появляются термины из другой области: отгул, отпуск, прогул, сверхурочный, повышение жалования,

15 М.Л. Л у р ь е, указ. соч., с. 500.

16 С.В. А л п а т о в, указ. соч. 
трудовой денъ. За этой лексикой не стоит никакая профессиональная область, а лишь организация труда и контроль занятости наемного работника. То, что для менеджера или офисного служащего не важна конкретная сфера деятельности, показывает сходство примеров 17 и 18 с тематически близкими ключевыми словами.

(17) Отче наш, иже иси в офиси. Да будет легок труд наш. Да уедет в отпуск начальство наше. Да исполнится воля наша. Аки на работе так и дома. Отгул нам насущзный дай нам сей день. И отпуск на сию неделю. И каникулы на сей месяи. И прости нам прогулы наши. Как и мы прощаем начальству нашему. Не введи нас в понижение. Но избавь нас от сверхурочного. Ибо есть твое изарствие в повышении жалования и сокращении трудового дня. И подай нам Асю, иже без нее не есть сия работа изарствие небесное. И погреби сисадмина под сонмищем дискет и компактов, чтобы гореть ему пламенем синим. Раскинь, Господи, райские кущи в виде баров u пабов по офису, ибо езмь сие великоблажие рабов твоих. Не покинь, Господи в трудные часы забвения утреннего, дай силы преодолеть тяготы головные. И возьми это лепту нашу в виде благодарственной молитвы Во имя контрола, альта и святого Delete. Peзет..., [http://ifun.su/anecdot/25445/].

(18) Молитва для служащих: Отче наш, иже еси в офиси! Да будет легок труд наш; Да уедет в отпуск начальство наше; Да исполнится воля наша, Аки на работе, так и дома. Отгул наш насущный дай нам на сей день, И отпуск на сию неделю, и каникулы на сей месяи. И прости нам прогулы наши, Как и мы прощаем наказания начальству нашему. И не введи нас в понижение, Но избави нас от сверхурочного. Ибо есть Твое Царствие в повышении жалованья И сокращении трудового дня. Аминь, [http://ifun.su/anecdot/25445/].

Как профессионально ориентированную мы рассматриваем также молитву модницы; ключевые слова, объединенные темой, показывают фокус интереса адресанта. Пример 19 является самым авторитето-зависимым, если так можно выразиться: текст организован онимами - именами модельеров, моделей, названиями форм и модных марок (Дольче, Габана, Кепzо, Кляйн, Живанши, Ив Сен Лоран, Герлен, Prada), а также их дериватами. Имя адресата - звательный падеж названия модного журнала „Космополитен”.

(19) Молитва модниц: - Космоди! Снизошли нам очки модные да шмотки новые бутиковыя! Дай Космо, здоровъя святой Дольче, Габбане и дочери их велико-модной Маноло Бланик. Снизошли всяческую моднодать и дисконтную карту Versace. Да снизойдет гламурный свет твоих страниц на премногобла-годатнейшую святую LacosT'y и брата ее блаженного Кепzо! Да не потемнеют волосы на голове Донны Каран и да не победят калории Великую Миуччию Prad'y Первомодную. Не обдели вниманием своим соратника нашего и покровителя Жана Франко Ферре, и да пускай благоухают пако-раббановские обновки Наоми благоговеннейшей Спапе Гью. Избави милостиво от цеелюлита и слоящихся ногтей на ногах блаженных моделей - великомученнии у пастырей наших Джимми Чу и Кельвина Кляйна. Да возблагоухают страницы твои бесплатными образцами святейших новинок от Живенши и Ив Сен 
Лорана. Во имя Герлен и Миа и Рудольфе Валенти-но. Мейбилин!, [httр://moda1tv. blogspot. com/2011/06/blog-post_07.html].

В молитвах обнаруживается и гендерный аспект (примеры 20, 21, 22).

(20) Женская молитва перед вечеринкой: „Господи, помоги мне не напиться! Проснуться утром в СВОЕЙ кровати, ОДНОЙ! Помоги не потерять имидж деловой женщины! Помоги не сесть попой $b$ салат! Не потерять вещи (и себя $b$ том числе)! Помоги не писать никому пьяных смс В 2 ночи! Не звонить, и главное - не признаваться никому в пюбви! (Во всяком случае не больше 2-ух раз). Помоги прийти домой на двух, а не на 4-ех! ...а если что и натворю..., то сотри мою память навеки веков! Аминъ!", [http://otvet.mail. ru/question/24289631/].

(21) Молитва женщины: Господи, молю, дай мне: мудрости, итобы понимать мужчину... ююбви, чтобы прощать его... И терпения кего настроениям... Потому что, Господи, если я попрошу силы... я просто забъю его до смерти!, [http://ifun.su/anecdot /51961/].

(22) МОЛИТВА ХОЛОСТЯКА. Господи, избавь от женитьбы... но если я все же женюсь, избавь меня от рогов... но если уж без рогов нельзя, пусть я об этом не узнаю... но если я об этом узнаю, пусть меня это не волнует!, [http://www.anecdotstatus.info /anekdot/i-25828.html].

Если анекдот-молитву можно считать жанром, обращенным на субъект, его социальный, профессиональный и гендерный статус, то анекдот, построенный на основе социологического опроса, обращен на социальные проблемы, отношения человека, общества и государства.

(23) На вопрос социологов: "Довольны ми вы тем как наше правительство проводит экономическую политику в последние несколько месячев?" 90\% респондентов выразили удивление тому факту, что наше правительство, оказывается, проводит экономическую политику, [http://www.respectme.ru/anecdote/statistics].

(24) Вопросы в анкете переписи населения:

1. Какого числа вы родились?

2. Какого года?

3. Какого хрена?... [http://www.respectme.ru/anecdote/statistics].

(25) Результаты опроса населения по поводу отношения к правительству:

- послать на .......... 46\%

- послать к.......... 29\%

- послать в ........... 14\%

- не определились куда... 11\% [http://www.respectme.ru/anecdote/statistics].

(26) Согласно данным статистики, девяносто из ста опрошенных россиян полностью одобряют государственную политику, а десять - всегда поддерживают. Остальные 150 милиионов никто никогда не спрашивал, [http:// www.respectme.ru/anecdote/ statistics].

Социологический анекдот диалогичен в своей основе, композиционно и содержательно он связан с серией анекдотов об армянском радио, а если пытаться определить его место во внутрижанровой типологии, в этом случае такой анекдот тяготеет к толкованию. В чем же 
различие? В том, что в социологическом опросе, как он предстает в жанре анекдота, не представлено коммуникативное намерение получить объяснение того или иного явления. В примере 23 респондент считает вопрос некорректным, в 24 - дискредитируется респондент, в 25 - сам предмет опроса.

Подведем итоги. Пародию относят к интертекстуальности, тем не менее в обоих рассмотренных случаях - при пародировании речевого поведения и жанра - мы говорим именно о пародии, потому что и в реплике, и в целом тексте переосмысливаются высказывания-доноры, понятые как законченные произведения. Узнаваемое речевое поведение или яркая реплика гиперболизируется, помещается в абсурдный, парадоксальный контекст.

Пародия на речевое поведение реального лица и тематические серии о киногероях, персонажах мультфильмов и книг обнаруживают сходства и различия. Сходства - в интертекстуальной природе обоих явлений; различия - в пародийности реплик исторических персонажей: Ленина, Брежнева или Ельцина, и в пародичности (в терминах Ю.Н. Тынянова) воспроизведения речи кино- и литературных персонажей в анекдоте.

Пародия на жанр воспроизводит композицию и речевые особенности текста-донора, но реагирует на навязчивость (в рекламе), неуместность (в объявлении), несоответствие формы и содержания (в СМС), ничтожность просьбы (в молитве), банальность и абсурдность (в социологическом опросе). Список жанров, которые могут подвергнуться анекдотическому пародированию, открыт.

На наш взгляд, целесообразно представить пародийность в анекдоте как поле: в центре будут анекдоты-пародии, ориентированные на другие жанры, затем игровая дискредитация узнаваемых реплик, принадлежащих известным людям, затем уже более свободное варьирование в тематических сериях анекдотов про героев книг, кино- и телефильмов.

\section{Источники текстов}

http://www.anekdot.ru/a/an9812/a981233;10.html

http://webideas.com/shtirlits/thinking.htm

http://anekdotov.net/anekdot/

http://joyreactor.cc/post/256965

http://polithum.ru/tag/boris-nikolaevich-elcin/

http://pda.anekdot.ru/tags/\%F1\%EC\%F1

http://sms-ok1.narod.ru/prikol.html

http://www.xa-xa.org/2008/07/28/molitva-studenta.html

http://carella.ru/anecdot/58516/

http://otvet.mail.ru/question/24289631/

http://ifun.su/anecdot/25445/ 